\title{
China, From Catch-up Growth to Innovation-Driven Economy
}

\author{
Yusuf Kurtoğlu \\ Undersecretariat of Turkish Treasury, Ankara, Turkey
}

\begin{abstract}
Chinese financial system and capital allocation to strategic sectors dominated by state banks made important contributions to the country's high economic growth rates during the catch-up stage of the last three decades. High household saving rates, fixed exchange rate regime, and extensive capital controls helped this stage as well. While the structural changes in the labor market conditions by moving from primary sectors to more capital intensive heavy industry, construction, commerce, and other service sectors have been contributed to the economic growth, competition, and productivity, due to the direct state governance or intensive interventions, competition and productivity have been curtailed on certain large industries. Aiming to eliminate this unproductive economic activity, enterprise sector reforms of China targeted restructuring the state enterprise's capital, organization, and management system. Besides, the reforms on science and technology system seek to participate in global production and R\&D networks by improving high-tech sectors through creating strong complementarity and collaboration between skilled human capital and educational interferences.
\end{abstract}

Keywords: primary \& capital intensive sectors, pillar \& strategic sectors, enterprise sector reforms, educational advancements, catch-up, science $\&$ engineering, innovation

\section{Introduction}

Developing economies' growth issues are discussed in the growth literature historically. The major reason of this issue has been seen as the total factor productivity differences among countries. In McMillan and Rodrik's study (2011), the problem was analyzed within the perspective of productivity differences between traditional sectors and industrial sectors. To improve the overall productivity in the economy, production factors, such as labor and natural resources, are supposed to move from rural to urban regions whereas mostly the capital intensive goods produced. Otherwise, it is hard to achieve and maintain the growth-enhancing structural changes in these economies with existing factor endowments. Besides the relevance of a market based exchange rate regime, the other structural conditions in domestic economies, such as relevance of the labor market regulations suitable with the internationally accepted ones and competitive goods markets, the level of participating into the global markets, affect also the growth prospect of these countries. Because, for example, the globalization activities increase, competitive conditions and the efficiency of production sectors improve.

Li and Whalley's study (2012) examined the relationship between China's future economic growth and trade bargaining. According to the simulation given in this paper, Chinese welfare gains from trade bargaining with the Organization for Economic Co-operation and Development (OECD) increase over time, if his present economic growth rates keep continuous (Rodrik, 2011).

Yusuf Kurtoğlu, Ph.D. in economics, Undersecretariat of Turkish Treasury, Emek/Ankara, Turkey.

Correspondence concerning this article should be addressed to Yusuf Kurtoğlu, Undersecretariat of Turkish Treasury, İnönü Bulvarı No. 36, Emek/Ankara, 06510 Turkey. 
China's transition from agricultural country to industrialized economy by copying and diffusing imported technology that is so-called "catch-up growth process" facilitated successively in the 1980-2010 period. During the transition stage, local governments' officials were rewarded by the central administration for the goals given, such as growth, foreign direct investment (FDI), employment, etc. Large size of the domestic market allowed the firms to operate in competition conditions and to reach scale economies. Establishment of special economic zones and accession into the World Trade Organization (WTO) in 2001 were the most effective policy implementations within the aspect of the integration of the country' economy with the global markets. Beside stable public budget balance and with the $25 \%$ public debt ratio to Gross Domestic Product (GDP), high saving and investment rates of China have been serving as the major engines of average $10 \%$ growth rates over more than three decades.

Nevertheless, Chinese catch-up growth policy created two major imbalances of overinvestment in some industries and external imbalances against cost of disadvantages to the rest of the world. Correction to these situations requires a series of reforms, including: (a) financing system; (b) improving competition conditions on state sectors both of finance and industrial sectors; and (c) foreign exchange rate and capital account liberalization. Then, transition from traditionally industrialized economy to the innovation driven economy requires more incentives, especially in educational systems and certain technological sectors reforms.

According to the World Bank report (The World Bank, 2012), and ECRAN (Ash, Porter, \& Summers, 2012), China is undergoing structural change in its sources of growth from investment to consumption driven economic growth model. To realize this, it is required to raise the household income and a gradual reduction in investment expenditures. The question at this point is how the country would be successful at this major transformation. Because, the country has fundamental challenges for these corrections, it is indicated in several researches, such as Akyüz (2011), Deer and Song (2012), and the World Bank (2012). "The disparity between consumption and investment" reflects the imbalance between wages and corporate profits. Thereby, tackling this problem by rising disposable income of household and per capita incomes requires radical policy changes and deployments.

Nonetheless, country's higher economic growth rates in recent decades create rise in current and future income level of least wage earners - hundreds of millions. The poverty rate in the country over the past three decades fell from $65 \%$ to $10 \%$ that about 500 million people were lifted from poverty. The country's per capita GDP reached to USD 4,382 (with purchasing power parity—ppp.USD 7,000) in 2010 (Cai, 2012). Per capita income was given as USD 155 in 1978 and USD 2,200 in 2009 in Fan, Morck, and Yeung's study (2012) with ppp.USD 3,700, and a fifth of US levels in Pilling's research (2012). In Heckman and Yi's study (2012), the per capita figure of China for 1976 is given as much as about $2 \%$ of that in the U.S.

Nonetheless, in 2010, the country by exporting $16 \%$ of world total exports as the largest exporter becomes the second largest economy in the world with produced USD 6tn valued output, $9.5 \%$ of global GDP. Besides, the share of Chinese middle income people is expected to be rise from $4 \%$ in 2005 to $56 \%$ in 2030 . Annual per capita income will reach to USD 16,000 by 2030 with more than three times of 2011 level (Chen \& Warren, 2011).

The remainder of the paper proceeds as follows. Financial sector developments are analyzed in section two, the developments in state-owned enterprises (SOEs) system and private sectors are examined in section three. The evolutions of high technology sectors are given in section four. Then, the conclusion remarks are specified at the remained-last section. 


\section{Financial System and the Impact on Economic Activities}

\section{Financial Institutions}

China's financial system has been dominated by the five largest state-owned banks in which the big four accounted for $51 \%$ of total RMB deposits in 2009 . Banking sector is responsible for $80 \%$ of corporate financing. The size of total bank credit to non-state sectors is 116\% of China's GDP over 2001 to 2007 that majority of it goes to SOEs and infrastructure investments and only a small fraction goes to hybrid sectors. The accounted share of banking sector domestic credits in GDP reached to $126.2 \%$ in 2008 and remained as $123 \%$ in 2011 . The scale and effectiveness of two stock markets (1990) in allocating resources realized quite weak in Chinese financial system, due to ineffective regulation and existence of speculative and insider trader structure. The stock market's share in GDP was remained 64\% between 2001 and 2007.

Besides banking system, the informal financial intermediaries (1980s), internal financing, coalitions of firms, investors, and local governments are also major affirming agencies which support the economic growth. This type of alternative financial sector sustained to form the various types of ownership structures called "hybrid sector". Within the context of alternative financing, hybrid sector's self-fundraising is accounted close to $60 \%$, the state sector's self-fundraising varied between $45 \%$ and $65 \%$ of total funds raised. The size of total self-fundraising, such as equity and bond issuance of all firms, grew at an annual average rate of $23.6 \%$ over the period of 1994-2009 and reached to USD 2,213bn at the end of 2009. After 1994 banking reform, the monetary authority largely maintained the stability on interest spreads between deposit and lending rates and net interest earnings share in total income reached $63 \%$ in 2009. These reforms help to increase total deposits and decrease in loan to deposit ratio during the 2003-2008 period (Allen, Qian, Zhang, \& Zhao, 2012; Liang, 2012a; Rabinovitch, 2012).

Because of the inadequate commercial orientation and regulatory framework, the financial system of the country has several weaknesses, such as to monitor, measure, and mitigate risks (The Word Bank, 2012). Besides, the rapid growth of state commercial banks' informal finance mostly devoted to SOEs creates asset bubbles and financial fragility that appears as one of the fundamental problems and weakness in both of the Chinese financial system and the economy. Therefore, further reform interferences expected in the areas, such as commercialization regulations including suspending the policy-government directed loans, improved allocation of capital and reliable monitoring, effective corporate governance, and bankruptcy rules regardless of ownership structures (The Word Bank, 2012).

Access of Chinese banks to foreign securities market is restrained with amount and content of investment by regulations. Despite share of foreign banks in source of total credits negligible and total assets which accounted as $2.16 \%$ of total Chinese bank assets as of 2008, entry number of foreign financial institutions has risen from 190 to 312 in five years after the country's WTO membership. The restrictions set by the regulation authorities for foreign ownership determined as: $25 \%$ equity investment as of the whole sector and own up to $20 \%$ of equity in a single Chinese bank.

Even some regulatory arrangements are introduced to support the securities markets in the past decade, "the structural restrictions", such as entry restrictions on financial institutions and controls on capital flows which easing gradually, are seen as the major obstacles to prevent the improvements of Chinese capital markets (Deer \& Song, 2012). Within the respect of more open financial system, monetary independence, and flexible exchange rate, it also appears as the basic requirements and complement to the market-friendly economy. 
The role of institutional investors, such as fund companies, increased after the year 2001 during which the investors allowed to freely withdraw capital. The total net asset value of these funds reached USD 328bn at the end of 2009. National social security fund was established in 2002 and had USD 143bn assets in 2010. Despite existence of the well developing "policy financial bonds" (municipal bonds) and government bond market between 1990 and 2009, the corporate bond market with 11\% share in GDP was operated as the least developed market in the country (Rabinovitch, 2012).

Fallowing 1998 reforms aimed to "establish new housing finance-individual mortgages and market systems", real estate markets were developed quite well and reached currently comparable in size with the stock market. The share of total real estate investment in national fixed assets investment increased from $12 \%$ in 1996 to $20 \%$ in 2010.

\section{External Surplus, Financial Stability, and Growth}

The exchange rate of the country for the USD was fixed between 1994 and July 2005. Then, tightly-managed exchange rate regime was applied till October 2011. Thereby, the country has maintained relatively stable exchange rate regime over the last few decades (Cheung, Chinn, \& Qian, 2012). This extensive capital control helped the financial stability. During this managed exchange rate regime, Renminbi(RMB)/USD exchange rate appreciated by $31 \%$. As a result, the government had been able to implement relatively manageable monetary policy within the respect of preventing the domestic inflation and supporting the export-led economic growth (The Word Bank, 2012).

Mostly by originating from continuous inflow of capital as FDI and excess of the foreign trade, large increases in foreign exchange reserves since 2001 reached to USD 2.9tn in 2010 and almost USD 3.5tn by the end of 2011, the largest reserves in the world. Primary source of accumulated net foreign exchange is predominantly, about $70 \%$ in the form of US government-issued securities. The current account surplus, for instance, grew from USD 37bn in 1997 to USD 305bn in 2010. Export surplus of the country reached to all-time high level of 8.80\% of GDP in 2007 and then returned to 4\% in 2009 and 2010.

Foreign surplus related economic problems and the measures are discussed in various studies, such as Allen et al. (2012), Prasad (2011a; 2011b; 2011c), the Word Bank (2012), and Deer and Song (2012) and analyzed in spirit as followings. Beside current account surplus, net financial account surplus which mainly is derived from rising net FDI inflows over the past two decades and portfolio inflows, reached to USD 3.2tn in June 2011. Under the relevance of monetary surplus in the economy, it requires central bank's intervention to the money markets by sterilizing the excess of the money supply through selling bonds to the banks and receiving cash back-ease the monetary expansion. Thereby, the authority are likely to avoid the fueling inflation and asset bubbles supports appreciation of currency and lower interest rate on domestic bonds. As another intervention tool, the money authority may increase the banks' obligatory reserve deposit requirements. If currency appreciates, it damages the export, employment, and disposable income in export sectors that cause decrease in aggregate demand and negative effects on the growth rate. Whereas a decline occurs in import prices, due to an appreciation of the RMB that stimulates rise in domestic consumption. Accumulated foreign exchange reserves support the higher levels of investment due to reduced cost of capital that administratively sets lower rate of interest.

\section{Real Economy: Production, Investment, Trade, and Competitiveness}

Controlling the expansion of sectors and larger enterprises is determined as the basic industrial policy 
drivers of the country. Besides, encouragement to technological advancement also proposed, within this context: (a) human resource developments; (b) R\&D and innovation incentives; (c) maintaining industrial and urban developments; and (d) improving energy efficiency and environmental susceptibility, such as developing alternative-energy sources and developing new automotive technologies, are determined as the major policy tools (The Word Bank, 2012; Ash et al., 2012).

The catch-up industrialization/economic growth in China is explained as "concentrated growth" (Deer \& Song, 2012) in which the resources are allocated to the industries with highest productivity and profitability and "uneven development" among and within sectors, industries, firms, and regions. The authors defined the period as an internal and external economic-imbalance period. The major reasons of those imbalances are given as: (1) declining share of labor income that falls from average $62 \%$ in $1980-1990$ period to $47 \%$ in 2010; parallel to this, a sharply reduced final consumption share of GDP over the past two decades (The Word Bank, 2012); (2) conversely the GDP share of investment rising sharply especially in the 1990s and 2000s. In 1978-2010 period, higher share of investment in GDP reached from 35\% to 48\% after 1990s and raised as $13 \%$ between 2000 and 2010 that supported the rapid capital accumulation. As the result of the investment in heavy industry in the early 2000s, both the outputs and exports of heavy machinery and transport equipment increased sharply. Between 2002 and 2007, while domestic-imbalance within the context of income and investment was maintained on one side and on the other, the sharp rise in the net trade surplus has occurred in the external sector. The external surpluses were sustained as the result of export-oriented industrialization policies which began to be effective by early 1990s in the country. Parallel to these policies, investment and export have become the main engines of economic growth in China at least in last two decades.

Besides, rising rates in household savings support the higher investment expenditures. After remaining relatively flat during the early 1990s, the average saving rate of urban households relative to their disposable incomes rose from $18 \%$ in 1995 to nearly $29 \%$ in 2009 . Total savings over GDP ratio raised from $72 \%$ in 2000 to $114 \%$ in 2009 (Allen et al., 2012). It is estimated that a decline in the pension replacement rate from $75 \%$ to $60 \%$ of pre-retirement income (in line with estimates for the transition generation under the reform) can explain a 6\%-8\% point increase in saving rates for households with heads in their 50s (Prasad, 2011d).

For the next two decades, GDP shares of investment and consumption were supposed to be changed from $46.4 \%$ and $48.6 \%$ respectively in $1995-2010$ period to $34 \%$ and $66 \%$ respectively in $2026-2030$ term. While fundamental declines were seen in both investment and consumption expenditures, parallel to this, saving rates would fall $10 \%$ during the same period. Industry and services sectors GDP shares would be changed from $46.9 \%$ and $43 \%$ to $34.6 \%$ and $61.1 \%$ respectively for the same periods (The Word Bank, 2012; Zhu \& Wan, 2012).

\section{Production Sectors}

During the catch-up period, more production factor, capital, and labor were added to the production system that majority of them were employed in industrial sectors and average annual growth rate was realized over 1995-2010 period as 9.9\%. In the pre-reform or central planning policies era (1949-1976) which also focused on industrialization and economic growth, skilled workers and physical capital/machines endowed in Chinese cities, which were realized higher relative to rural areas. With respect to human capital, literacy rates were improved from about $20 \%$ in 1949 to $68 \%$ in 1982 and special emphasis was put on secondary and higher education in the schools located in cities. School enrollments of the country in 1975 for primary and middle 
schools were as high as $96 \%$ and $60 \%$ respectively. Compulsory Education Law of 1986 requiring nine years of education raised overall educational attainment during the 1997-2006 period and returns to education have determined about $20 \%$ per year on average. In late 1978, collective production system was changed to private capital ownership-market oriented production system formed as the "town and village enterprises" that were peculiar to China, by early 1980s. This policy facilitates by the mid to late 1980 s, to increase the incomes and industrial goods consumption of rural population (Banerjee, Duflo, \& Qian, 2012; Zhu \& Wan, 2012; Heckman \& Yi, 2012; Kroeber, 2012; The Word Bank, 2012; Fang, Eggleston, Rizzo, Rozelle, \& Zeckhauser, 2012).

The industry policy oriented by the Chinese state has been depended upon formal and informal entry barriers for much of the manufacturing enterprises in which the activities were operated by SOEs for the determined "strategic" seven sectors in the year 2006. Within this context, state has an "absolute control" on the sectors, such as defense, electricity generation and distribution, petroleum and petrochemicals, telecommunications, coal, civil aviation, and water transport. Furthermore, machinery, automobiles, electronics and information technology, construction, steel, base metals, and chemical industries have been designated as the "pillar" industries that the state has strong influence on. While this structure of SOEs discouraged new entrants and created major distortions in fair competition environment and innovation investments, it also allowed some tendencies of overinvestment in some of the heavy industries, such as cement, steel, machinery, and transport vehicles.

Besides, the cost reduction policies of food and raw materials by Chinese state, for industrial sectors allowed to increase in profitability of SOEs operate in these sectors. The capital requirement of these establishments also meets with low cost (Grabowski, 2011). After the resource was transferred from primary sectors especially from agriculture to industry, by 1990s, SOEs retained a commanding role in Chinese economy. But, the role of private sector increased in years and reached to much bigger share by the end of 2010 (Cheung et al., 2012).

Within this context, improvements in transportation infrastructure which began during the 1980s, contributed to market integration by reducing price volatility and trade cost and promote factor mobility, such as labor and capital. Thereby, it could be possible to reallocate the resources in order to facilitate the comparative advantages. This brought the regions closer to transportation networks which have higher level of GDP per capita, higher number of operating firms with higher average profits (Banerjee et al., 2012). Interferences in this sector continue by 2010 s with large size of planned projects, such as 25,000 km high-speed rail system and 70 new airports could be realized over the next five years.

The entry barriers to the sectors that SOEs have been operating are supposed to reduce the potential growth rate of GDP and total factor productivity (TFP). Therefore, to improve the market-oriented economic activities further, China needs to change this SOE and state-owned banking originated monopoly type production and financing system. This system should be towards the system works under the competition and anti-trust policy rules. Within this context, "rise in dividend payments and further privatization of the SOEs, and unified corporate tax reform for all firms allow more effective allocation of capital, more investors to enter the market and contribute rise in household consumption" (The Word Bank, 2012, pp. 25-26; Deer \& Song, 2012, pp. 22-23).

Further reforms of production/enterprise sector should be comprised of restructuring the SOEs capital, organization, and management system to more market-oriented working firms and support either new entrants to the market or entrepreneurship in general. By implementing the predictable and market-friendly industrial 
policy, it could be possible to create more favorable environment to the firms, thereby facilitating the resource uses more efficient. Enterprise reforms should precede also financial sector reforms. Besides, reforms of input markets, i.e., land, labor, and capital are also required to prevent distortions in factor allocation (The Word Bank, 2012).

\section{Factor Market Developments}

Factor reallocation among sectors as a policy dimension contributes to the improvements in labor, TFP, and competitiveness of the industrial sectors. Better earning conditions support the structural changes in the labor factor by moving from primary sectors to more capital intensive heavy industry, construction, commerce, and other service sectors ( $\mathrm{Li} \&$ Whalley, 2012). While a positive contribution of labor input in GDP was realized for the period from 1985 to 1997, the share has reverse to negative sign for 1998-2007 period. Contrary to this, average marginal product of capital for manufacturing raised two times higher in 1998-2007 period compared to 1985-1997 period. Because, together with the capital allocation and capital deepening, technological improvements in manufacturing have increased by the late 1990s. Nonetheless, China's capital stock per worker is just $8 \%$ of the US and nearly $2 / 3$ has been created since 2003 . Inward FDI in manufacturing sectors which amounted $63.6 \%$ of total FDI in 2006 also contributed to the positive developments in these industrial sectors. As the result of these developments, the share of primary industry in GDP and employment fell by $17.2 \%$ and $14.1 \%$ respectively, but tertiary sector's share of GDP and employment rose by $11 \%$ and 9.4\% respectively in 1985-2007 (Yao, 2010).

Having the advantages of higher working-age population/ample labor supply and a high saving rate, it has contributed positively to the economic growth in past several decades. But, the expected GDP growth rate was supposed to be negatively affected by the number of people aged 65 years and above reached to $8.9 \%$ of total population in 2010, and the dependency ratio (retired/working people) will rise more in the 2011-2015 period (12th Five-Year Programme-12th FYP). The slowdown of both of the labor supply and saving rate, together with the rising wages of ordinary workers since 2004, causes a gradual decline in growth rate of the country from an average of $8.6 \%$ in 2011-2015 to $5 \%$ in 2026-2030. For instance, share of investments to GDP should be falling by $12 \%$ and comes to $34 \%$ by 2030 (The Word Bank, 2012; Cai, 2012).

\section{Investment, FDI, and Trade Developments}

High household saving rates and capital allocation to strategic sectors by state-owned banks during the catch-up stage of the last three decades made important contributions to the country's high economic growth. Correspondingly, SOEs by having been mostly preferential access to bank financing and other business opportunities realized $53 \%$ of non-agricultural fixed investment. Nonetheless, their activities find inappropriate with the fair competition rules. SOEs share in total industrial assets and employment declined from $68.8 \%$ and $60.5 \%$ to $42.4 \%$ and $19.4 \%$ respectively in $1995-2010$ period. The share of these enterprises in total export also fell from $57 \%$ to $15 \%$ at the same period. With the planned enterprise sector reforms, the share of SOEs in industrial output was supposed to be declined from $27 \%$ in 2010 to $10 \%$ by 2030 (The Word Bank, 2012). On the contrary, hybrid sectors employ the majority of the labor force and contribute most of the China's economic growth (The Word Bank, 2012; Deer \& Song, 2012; Liang, 2012b; Allen et al., 2012). New entries' contribution has been found over $2 / 3$ of TFP growth. Non-state enterprise sector by having $65 \%$ of China's patents and $70 \%$ of innovations was found much more productive, profitable, and innovative than that of SOE sector. 
Trade and FDI together with the domestic investment are envisaged as the major sources of economic growth and TFP in China for the last three decades. In 2001-2009 period, annual averages of the shares of Chinese export, import, and FDI in GDP are calculated as 29\%, 25\%, and 12\% respectively (Kurtoğlu \& Gür, 2011). The country is closely participating in international production networks; about $60 \%$ of total imports and over $80 \%$ of intermediate goods imports are used for exports and the rest for domestic consumption and investment. Benefits are larger due to imported intermediates in contribution to the TFP and expanding the exports of firms operating in R\&D intense sectors (Feng, Li, \& Swenson, 2012). The country's investment growth is correlated with its export growth. A substantial share of import is subsequently incorporated into Chinese export (Cheung et al., 2012). Despite the high import content of China's exports especially in processing trade, one third of growth in the country's income comes from exports. During 2004-2008 period for instance, the contribution of exports to the GDP growth was calculated as $15 \%$ for net exports and about $1 / 3$ for the case of import-adjusted export is considered. The share of "processing exports" where foreign firms are dominant, in total exports, fell below $50 \%$ in 2008 ; rise in the share of domestic inputs in processing exports allows domestic value-added contents of exports rising. Contrary to this, the calculated domestic firms share in total exports about $80 \%$ in 1991 declined dramatically to nearly $45 \%$ in 2007 on behalf of foreign firms. For the import case, the share of total imports used for domestic consumption and investment is $15 \%$ and $35 \%$ respectively, part of which investment is directly related with the exports. But income is earned from exports which profits consist two thirds of value-added in exports and the rest goes to wages and generates less consumption, due to lower propensity of consumption from profits and higher share of foreign owned export companies. Parallel to these developments, by the years of 2000s adverse to the GDP share of profits in general, the share of consumption and wages in GDP declined from about $46 \%$ and $52 \%$ to $36 \%$ and $40 \%$ respectively. These figures explain how Chinese economic growth depends on export and investment dynamics rather than consumption driven growth prospect (Akyüz, 2011).

Together with the technological spillover effect that a $1 \%$ increase in the FDI inflow promotes domestic firm labor productivity by $5.77 \%$, FDI also contributes to increase in capital stocks, domestic employment, and competition in the country (Sun, 2011). Developed countries, due to comparative advantages, by locating their labor-intensive segments of the production chain into the low-cost countries such as China, not only facilitate the FDI activities but also contribute on bilateral trade relations. In vertically fragmented production process, the goods are subject to trade for different subsections of the same industry, such as the intermediates and final goods. Thereby, by splitting into several production steps and locating the production process beyond national borders, vertical intra-industry trade occurs. The level of intra-industry trade among countries indicates the level of inter-industry trade, as a result of specialization degree of each country in different industrial sectors (Dettmer, Erixon, Freytag, \& Tremblay, 2011).

In Sun's study (2011), the average FDI-invested firms' rate was given as $28 \%$ of total employment at manufacturing sector in 2003 which the data account for more than 181,188 manufacturing firms which produce $85 \%$ of the total industrial output in China. In the same search, it has been found that export intensity, bigger domestic market, low cost of production, and labor quality-efficiency have a positive impact on foreign presence and significantly attract FDI inflows into the country. These structural conditions encourage transnational/multinational corporations (TNCs) to import raw materials and intermediate products for processing and then export. 
The number of TNCs investing to the country is increasing, due to rapidly becoming richer domestic market, supporting industrial environment, better infrastructure, and rising skilled human capital supply. It has been found that FDI is complementary to the human capital and the importance of low labor cost respect to investment decision reasons of TNCs has been decreasing. Between 1980 and 2007, the number of approved FDI in the country reached total 632,298 and the investment value of foreign-funded enterprises amounted as USD 766,665bn. The country's FDI inflows in 2001-2009 period for instance, as an annual average, increased by $9 \%$ and its share in GDP was realized as $12 \%$ (Kurtoğlu \& Gür, 2011). Over $60 \%$ of total foreign capital was utilized in industrial sector. The share of foreign capital in total paid-in capital rose from $20.2 \%$ to $26.1 \%$ in selected 20 industrial sectors in 1998-2006 period. For most of these industries, annual growth rate of size (gross output, added value, and assets), TFP, and exports are found to be higher than overall industry level of the country in this period (The Word Bank, 2012; Danhui, 2010).

Among all the manufacturing sectors subject to exports, the most globalized industries arised are machinery, automobiles, electronic communications, instruments and meters, food processing, and chemical engineering sectors. These sectors integrated with global production system and the foreign shares raised more and varied between nearly $20 \%$ in chemical and transportation and $69 \%$ in electronic communication in the same period of 1998-2006 (Danhui, 2010).

While EU, the US, and Japan (G-3) are the main export markets for China, the country has received only $12 \%$ of FDI inflows originated directly from these three countries/regions (Liu, 2009). In Kurtoğlu and Gür's study (2011), for the G-3 countries in 2002-2009 period, the annual average increasing rate of total and high-tech goods export to China and imports from China are higher compared to their total and high-tech goods export and import rising rates in the cases of trade with each other and trade with rest of the world.

From early 1990s to 2010, structural changes happened in the pattern of the country's exported goods, i.e., from agricultural products to machinery and transport equipment sectors. While the share of manufactured goods in total export was $20 \%$ in 1993 , even with the high income elasticity, it has raised about $10 \%$ per annum and accounted for most share in 2010. The share of primary products-commodities, particularly oil in China's total import, has become much more substantial and has exhibited more substantial movements which were affected also from large swings in price of oil over the recent years (Cheung et al., 2012; Dettmer et al., 2011).

According to EU study of Ash et al. (2012), Chinese 12th FYP predicts that domestic consumption was supposed to be increased during the 2011-2015 period. The planned measures within this extent have been determined as: increases in social insurance coverage; rise in employment and wages; increases in subsidies-deepening reform of the income distribution system; and rise in service sector activities. Additionally, it facilitates an increase in consumption in consumer durables, electronics-mobile phones, computers, cars and brand-name products, housing, education, health, and transport. Actually Chinese middle-income consumers' consumption has doubled since 2005 . The plan provides a $7 \%$ annual growth in per capita income and that meant the rise in total retail sales from Euro 1.9tn to Euro 4.9tn during the plan period of 2011-2015. Besides, tax reform should be done on behalf of consumers. Rise in aggregate consumption allows higher imported consumer goods and inward FDI levels compared to the current levels. Twelve FYP envisaged a complementarity between FDI inflow and outward FDI as a "new trend" that seeks for exploring new markets, new oil, natural gas resources, and export/import balance of the country to become more closer. 


\section{High-tech Sectors, Complementarity, and Collaboration}

China's technology transfer attempts began in late 1990s, through acquisition of foreign intellectual property (IP) and FDI by encouraging multinational corporations to conduct their R\&D in the country. "New technologies" stated in Science and Technology Development Plan 2006-2020 comprised of ICT, biotechnology, nano-sciences and nanotechnologies, materials, and energy. The plan encourages to talent scientists and improves the management and coordination of technological researches. Besides, physical, life, space and earth sciences, nano science, and technology are determined as the major breakthroughs in basic research, science, and frontier technology in the 12th FYP. The major targets of these plans are promoting enterprise-led innovation, raising R\&D expenditures, and patenting attempts to create a more innovation-driven economy, for example, the R\&D expenditures share, accounted as $1.75 \%$ of GDP in 2010, planned to reach to $2.2 \%$ by 2015 . Within this context, the proposed strategy is determined as the market-oriented and industry-education-research integrated technology innovation strategy. According to the accepted foreign trade policy, it is planned to export the goods that have brand and quality and contain more technology, such as electronics and other high-tech products, and import the technological parts and components, scarce resources, and consumption goods (Dong, Li, \& Zhang, 2011).

Determined major high-tech industries that Chinese companies mastering are: auto assembly and components, PVCs, biopharmaceuticals, nanotechnology, stem cell therapeutics, high density power batteries, high speed trains, telecommunication equipment, wind turbines, passenger aircrafts, booster rockets, space satellites, supercomputers, shipping containers, internet services, electric power turbines, etc. Facilitating the targeted innovation economy, governments have been supposed to encourage the R\&D activities through tax incentives and supporting the creation-establishment of technology centers within large firms and collaboration of enterprises and research institutions (The Word Bank, 2012; Ash et al., 2012).

Fast accumulation of physical capital via FDI inflow in China between 1979 and 2008 reached to USD 1.1 th and caused to increase not only demand for skilled workers but also return to education. Complementarity effect of the country's education policy considerable supported this process. China's science and technology system reforms began in 1980s and the country's skills in this area, including research infrastructure and ICTs, were improved since then. As a result of these reforms, for instance, exports of low, medium and high tech goods, business R\&D, and patenting increased. Actually, the country has had a good initial performance of education level which allowed the fundamental improvements in skilled human capital base. Despite that China is an unskilled human capital abundant country, the compulsory education —up to junior secondary has been well implemented in the post-reform period of 1984-2000 (closed to OECD averages in 1990s). Besides, the addition years of higher education was supposed to raise aggregate skilled human capital as well. As a result of the radical policy implemented in 1999 aiming to expand the higher education, college graduates increased from 960,000 in 2001 to $6,350,000$ in 2010 . By 2010, the country had 8,930 college graduates for every 100,000 people, and having 120 million college degree that could swell by 200 million over the next two decades. Tertiary school enrollments also raised by $16 \%$ point during the same period. Even, the number of Chinese students studying abroad reached to almost 180,000 in 2008. Together with these developments in higher and tertiary education, the contributions of the complementarity between new technologies mostly entered into the country via FDI inflows and skilled workers caused dramatic increases in "marginal productivity of especially skilled workers" (Heckman \& Yi, 2012; The Word Bank, 2012; Fang et al., 2012). 
Changing structure of Chinese industry in terms of technological contents that proves the "low-cost labor related comparative advantage structure" has been changing. The reallocation of production factors towards the advanced technology industries is supporting and improving in the country. This change could be seen also within the context of trading goods. More than $80 \%$ of trade between EU and China is found as interindustry trade for instance, which explains how the two regions have comparative advantages in different industries. Despite this reality, the EU's share of the labor-intensive imports from China declined by around $10 \%$ between 1999 and 2008. Even, the share of human capital intensive goods in EU foreign trade, both exports to China and imports from this country, rises around 20\%. In "bilateral technology intensive products trade with China", EU's competitiveness is slightly declining and China is becoming a value-added/technological-advanced goods trading partner. The trade expansion in the technology-intensive industries has been found mostly in intra-industry type in 1999-2008 period (Dettmer et al., 2011). In Kurtoğlu and Gür's research (2011), China's high-tech goods export and import increase rates to and from the EU, the US and Japan were calculated as $26 \%$ and $22 \%$ respectively in 2002-2009 period which were higher than the country's total-trade values for the same country destinations and the same period.

TFP makes a significant contribution to the country's economic growth which indicates the level of technological improvement of the country. While the physical capital contributes $2.2 \%$ to industrial output during the period 1978-2004, the contribution of TFP was realized as $4.4 \%$ at the same period. Shares changed as $3.2 \%$ and $6.2 \%$ respectively for capital and TFP from 1993 to 2004 . The electrical and nonelectrical machinery, office equipment, and telecommunications manufacturing are R\&D intensive and realized rapid improvements in technology-granted patents and had higher TFP rise between 1981 and 2008 (The Word Bank, 2012). The increase in TFP share with $2 \%$ which is higher than the capital share's rising rate in manufacturing sectors, explains how the country progressed through the technological catching-up targets via $R \& D$ and innovative activities.

According to World Bank (2012), China will have to rely more on productivity growth with the contribution of improved allocation of capital. But, R\&D and innovation related indicators show that China yet does not reach the developed world levels. The share of R\&D to GDP was explained as $56 \%$ of the level of the developed countries. The number of R\&D workers for every 10,000 persons and the owned patents by every 1 million people is only $23 \%$ and $15 \%$ of the level of what developed countries have respectively. Average length of education for the population aged 30 years also lower comparatively than for instance, $65 \%$ and $67 \%$ of the level of the US and Japan, respectively (Cai, 2012).

The country ranked 29th among 125 countries in 2011 by Global Innovation Index that measures the capabilities of the economies related with the innovation input (e.g., institutions, human capital, infrastructure and market, and business sophistication) and output indicators. Although the research infrastructure and numbers of researchers have expanded, there are still insufficiencies at the areas as quality, experience, manifold, and institutions related with innovation. Further development of the innovation activities requires the efficient technology policies including creating an innovation system alive to the global markets and open nature of innovative activities (The Word Bank, 2012).

The origin and content of the innovation activities, due to rising competition conditions in world markets have been changing. While the innovation activities were targeted through technological catching-up in industry and services previous decades, henceforth the shape is changing through the system that requires to combine different existing technologies or introduce innovative designs and special features customizes for 
different consumer groups. Parallel to these requirements, China gradually renews its innovation strategy.

One of the directions of new strategy of China for 2030 is the encouraging innovation and adopting an "open" innovation system with links to global R\&D networks. Within this respect, the only most important viable economic policy was envisaged as the "ensuring free and fair competition conditions". The major tools of this policy consist of such public arrangements as improving the quality and efficiency of public services, improving human resources and further liberalization of FDI in service sectors, rather than giving preferential incentives to the determined sectors. Within this respect, the integration of FDI's and foreign R\&Ds into the domestic R\&D projects and activities was seen as another important policy implication. Thereby, expecting to compete within the same product space as advanced countries and under the conditions of collaboration and specialization, benefit could be possible from not only global production networks but also global R\&D networks (The Word Bank, 2012). Therefore, the expected change in structure of employment is the shift from labor intensive to skilled intensive activities, and an increase in the pace of innovation with the contribution of rising educational standards and tertiary education (The Word Bank, 2012; Chen \& Warren, 2011).

Within this context, in the first stage 2011-2020 of transformation program prospects to the "planned national innovation system", it was defined as strengthening the research infrastructure and the system, open, globalized, market-oriented, and compatible with a market economy. The programme anticipates the increase in basic research, realizes university reform, improves both quality and quantity of science and technology, and empowers the links in key industries. In this first decade, opening of product markets, enforcement of laws regulating competition, and protecting intellectual property are seen as the major innovation related legal regulations. In the second stage 2021-2030, it generates new ideas and puts them into operational and embody to the Chinese TNCs which are to seek competitiveness through innovation and able to engage in technological exchanges and partnerships in world markets. Government was supposed to encourage the TNCs to establish $R \& D$ centers in the country and also encourage the home grown TNCs to participate in international R\&D arenas, thereby, collaborating with the global innovative networks (The Word Bank, 2012).

China's advantages, for improving its innovation system that aims to participate to global production and R\&D networks, were explained in Word Bank report (The Word Bank, 2012) given as: the scale and wide ranging capabilities of manufacturing sector, the large supply ability of science and engineering skills, and the elastic supply of capital to support innovative firms; large market-middle class is expected to double in the coming two decades-allows domestic producers to attain scale economies, clusters, and agglomeration, attracts TNCs and innovation, entrepreneurial culture in several provinces supportive to small business and start-ups, and state sector reforms (privatization etc.) which began in 1996-1997.

Challenges and constraint on innovation initiatives stated in Word Bank report (The Word Bank, 2012) as: weak domestic consumption, unproductive SOE system, low research quality, and TNCs hesitations; for IP protection, domestic content requirements, technology transfer to China in exchange for market access, exclusion from government contracts, and also the returns from R\&D spending not thoroughly evaluating due to distance from market-directed innovation-learning-research system, i.e., lack of experience, efficiency, intensity, and innovation related institutions. Besides, even the positive developments were realized in human capital accumulations, senior secondary and higher education were still scarce in the country and considered to take time to upgrade the human capital stock. Moreover, the ratios of human capital endowed with higher education vary among the regions. While the northeastern region for instance has the highest ratio, the eastern region lags behind it, the western region stays close to national average, and the southern region is lower than the average. 


\section{Conclusions}

During the catch-up period of China, credit creation and capital allocation policies especially towards the strategic sectors have made important contributions to the high growth rates. Beside, high household saving rates, fixed exchange rate regime, and extensive capital controls also contributed positively to this stage. As a result of the openness policy on FDI and trade, it was allowed to raise not only in international industrial transfer abilities but also in technology transfers of foreign-funded firms that facilitated the country's growth substantially since the mid-1990s. FDIs for instance, through positive technology spillover effects, were acted as complements to the rise in TFPs and development of human capital endowed with higher education. At the same time, these developments have made also a significant contribution to production efficiency and improvements in competitive advantage.

Nevertheless, while the structural changes in the labor factor by moving from primary sectors to industry, construction, and service sectors contribute to economic growth and productivity in general, competition and productivity have been curtailed on certain large industries. Therefore, serious imbalances, such as lower wages and inadequate consumption, and external surplus occurred in the economy. Due to these imbalances and in order to improve the competition conditions, certain reforms necessitated in both of the finance, including capital account and foreign exchange liberalizations, and industry sectors operated via market-based private entities. The imbalance between wages and corporate profits is a remained problem of Chinese economy and for the solution, it requires further radical policy changes and deployments.

Chinese growth prospects were supposed to be reversed by changing investment and net export dominant economic growth structure to private consumption and investment dominant growth path. In order to stimulate such a sustainable growth prospect, the government should encourage the consumer spending by tax reductions and/or increase the size of its welfare safety nets. Within this context, China's future development requires more efficient services sector and more diversified manufacturing products in order to meet the raising domestic demand.

Then, for the succeed and completion of transition from traditional industrialization to innovation-driven economy by developing certain new-technological sectors, further regulations and reforms are required especially in skilled human capital endowed higher scientific and engineering education.

\section{References}

Akyüz, Y. (2011). Export dependence and sustainability of growth in China. China \& World Economy, 19(1), 1-23.

Allen, F., Qian, J., Zhang, C., \& Zhao, M. (2012). China's financial system: Opportunities and challenges (National Bureau of Economic Research-NBER working paper 17828, February).

Ash, R., Porter, R., \& Summers, T. (2012). China, the EU and China's twelfth five-year programme. London: ECRAN.

Banerjee, A., Duflo, E., \& Qian, N. (2012). On the road: Access to transportation infrastructure and economic growth in China (NBER working paper 17897, March).

Cai, F. (2012). Is there a "middle-income trap"? Theories, experiences and relevance to China. China \& World Economy, 20(1), $49-61$.

Chen, A. H., \& Warren, J. (2011). Sustainable growth for China. The Chinese Economy, 44(5), 86-103.

Cheung, Y. W., Chinn, M. D., \& Qian, X. W. (2012). Are Chinese trade flows different? (NBER working paper 17875, March).

Danhui, Y. (2010). Foreign direct investment and development of high-growth industrial sectors in China, 1998-2006. The Chinese Economy, 43(4), 93-114.

Deer, L., \& Song, L. (2012). China's approach to rebalancing: A conceptual and policy framework. China and World Economy, 20(1), 1-26. 
Dettmer, B., Erixon, F., Freytag, A., \& Tremblay, P. O. L. (2011). Dynamics of structural change, trade between the EU and China. The Chinese Economy, 44(4), 42-74.

Dong, Y., Li, K. W., \& Zhang, D. (2011). Determinants of Chinese and American outward investment. The Chinese Economy, 44(2), 58-77.

Fan, J., Morck, R., \& Yeung, B. (2011). Capitalizing China (NBER working paper 17687, December).

Fang, H., Eggleston, K. N., Rizzo, J. A., Rozelle, S., \& Zeckhauser, R. J. (2012). The returns to education in China: Evidence from the 1986 compulsory education law (NBER working paper 18189, June).

Feng, L., Li, Z., \& Swenson, D. L. (2012). The connection between imported intermediate inputs and exports: Evidence from Chinese firms (NBER working paper 18260, July).

Grabowski, R. (2011). China's economic takeoff. A few similarities with Japan. The Chinese Economy, 44(2), 5-24.

Heckman, J. J., \& Yi, J. (2012). Human capital, economic growth, and inequality in China (NBER working paper 18100, May).

Kroeber, A. R. (2012). Bear in a China shop. Retrieved from www.brookings.edu/research/opinions

Kurtoğlu, Y., \& Gür, A. İ. (2011). Structural change in production and trade. Proceedings from International Congress on Knowledge, Economy and Management Congress-ICKEM, Sarajevo, Bosnia \& Herzegovina.

Li, C., \& Whalley, J. (2012). China's potential future growth and gains from trade policy bargaining: Some numerical simulation results (NBER working paper 17826, February).

Liang, Y. (2012a). Development finance, China's banking system in light of the global financial crisis. The Chinese Economy, $45(1), 8-27$.

Liang, Y. (2012b). China's short-term and long-term development after the 2007 global financial crisis: Some critical reflections. The Chinese Economy, 45(1), 3-7.

Liu, L. (2009). Impact of the global financial crisis on China: Empirical evidence and policy implications. China and World Economy, 17(6), 1-23.

McMillan, M. S., \& Rodrik, D. (2011). Globalization, structural change and productivity growth (NBER working paper 17143, June).

Pilling, D. (2012). Don't believe the bears: The wobbly panda won't fall yet. Financial Times. Retrieved from http://www.ftchinese.com/story/001044746

Prasad, E. (2011a). Rebalancing the U.S.-China relationship. Washington, DC: The Brookings Institution.

Prasad, E. (2011b). The U.S.-China strategic and economic dialogue: A preview of key economic issues. Washington, DC: The Brookings Institution, May 06.

Prasad, E. (2011c). The yuan's reckoning. Wall Street Journal. Retrieved from http://www.wsj.com/articles/SB10001424052702304186404576387073202660258

Prasad, E. (2011d). China's approach to economic development and industrial policy. Washington, DC: The Brookings Institution.

Rabinovitch, S. (2012). Chinese business embarks on bond issuance boom. Financial Times-News Analysis. Retrieved from http://www.ft.com/intl/cms/s/0/839017b4-cbf8-11e1-839a-00144feabdc0.html\#axzz3uO2sPnFU

Rodrik, D. (2011). The future of economic convergence (NBER working paper 17400, September).

Sun, S. (2011). Foreign direct investment and technology spillovers in China's manufacturing sector. The Chinese Economy, 44(2), 25-42.

The World Bank. (2012). China 2030, building a modern, harmonious, and creative high-income society (Conference edition-report, February, 28).

Yao, Z. (2010). Factor reallocation effect and productivity in China's economic growth, 1985-2007. The Chinese Economy, 43(1), 44-70.

Zhu, C., \& Wan, G. (2012). Rising inequality in China and the move to a balanced economy. China \& World Economy, 20(1), 83-104. 